$\begin{array}{llll}\text { Submitted } & : 06.10 .2020 & & \\ \text { Accepted } & : 20.11 .2020 & & \\ \text { Year } & : \text { December } 2020 & \text { Volume: } 1 \quad \text { Issue: } 2 \\ \text { DOI } & : 10.47333 / \text { modernizm.2020265820 }\end{array}$

\title{
JEANETTE WINTERSON'S THE STONE GODS: VOICING A POSTMODERNIST EMBODIMENT
}

Najmeh Nouri ${ }^{1}$

\begin{abstract}
Jeanette Winterson's The Stone Gods (2007) displays a new conceptualization of the body that tends to disfigure the unified perception of human subjectivity. In this fashion, Winterson renders a posthuman concept of the body that resists the notions of origin or end. Accordingly, The Stone Gods is a manifestation of posthuman bodies that transgress the boundaries and are in a ceaseless condition of becoming. In this sense, the posthuman body is not a stable and predetermined concept but rather it embodies continual change with an ability to produce alternative possibilities. Winterson's perception of the posthuman body aligns well with Deleuze and Guattari's concept of "becoming-revolutionary" through which they defy any kind of static conceptualization including human subjectivity. Within the Deleuzoguattarian perspective, becoming operates through making "assemblages" including human/machine, human/animal, and human/plant. The alliance that is formed by the process of making each assemblage produces multiplicities of bodies including the posthuman body. This type of body is neither human nor nonhuman, but it shapes a unique thisness, "haecceity" in Deleuzoguattarian terms, that is beyond gender and origin. Thus, the posthuman body acts as a threshold that allows the rhizomatic movement from one body to another one.
\end{abstract}

Keywords: Postmodern, Posthuman, Deleuze and Guattari, Jeanette Winterson, The Stone Gods.

\section{Introduction}

The concept of the body occupies a vital position in humanities, particularly in literary studies. It takes on a different significance when many contemporary writers, like Jeanette Winterson, subvert the unified perception of corporeality and instead focus on a new understanding of the body that is posthuman, thus, including all organic and inorganic entities. In her prolific novel, The Stone Gods, Winterson reflects on both human and nonhuman bodies to render a novel reconceptualization of embodiment in which the body is defined through its relationship with social, political, and economic factors. In this perspective, Deleuze and Guattari maintain that bodies are made "on a "plane of immanence' in which things, objects, and beings are understood not in terms of eternal and immutable essences, but in terms of relations and effects" (Braun 8). Insofar as posthuman bodies consist of multiplicities, Deleuze and Guattari's perception of the body is posthuman since they place the body in a relational context that is far from being a merely passive body which is inscribed and produced by social context. Deleuzoguattarian posthuman body, however, is reconfigured in contextual categories, suggesting an embodiment that interrogates not the function of the body, "but by what they can do, by the affects of which they are capable in passion as well as action" (Deleuze and Parnet 60). Unlike the physical body with organs that has a limited number of relations with its environment, the Body without Organs $^{2}$ has an infinite capacity to create new possibilities. According to Deleuze and Guattari, the Body without Organs can affect and be affected by other bodies including biological, cultural, social, and political bodies. The Stone Gods narrates the story of multiple bodies, biological

\footnotetext{
1 Lecturer, School of Foreign Languages, Izmir Democracy University, najmeh.nouri@idu.edu.tr, https://orcid.org/0000-0002-3573-0498.

${ }^{2}$ Deleuze and Guattari adopt the concept from a radio play, To Have Done with the Judgment of God, written by Antonin Artaud: "When you will have made him a Body without Organs, then you will have delivered him from all his automatic reactions and restored him to his true freedom" (Artaud, [1947] 1976: 571). Artaud denounces the concept of the body for its restricting effects on individuals. He believes that the body is an externally organized structure, and it is also subjugated by its organs. Artaud suggests distorting the body through changing the place of its organs.
} 
and cyborg, who establish a variety of relationships with their environment and thus, producing new possibilities that allow them to transgress the limits of the physical body. Drawing on the Deleuzoguattarian concept of Body without Organs, this paper aims to discuss how Winterson discredits the static forms of embodiment through suggesting a fluid type of the posthuman body. In other words, The Stone Gods presents a posthuman type of embodiment to put into question the coded human subjectivity that is basically anthropocentric. Winterson focuses on a diversity of bodies such as nonhuman cyborgs, queer subjects, and abject cancerous mutants to present a new way of thinking about human limits.

\section{Body Politics: The Human And Technology}

Depicting the posthuman body through involving species other than human and marginalized groups like women and racial Others is the main preoccupation of Winterson's novel. The Stone Gods narrates a relationship between a Homo Sapiens named Billie, and a Robo Sapiens called Spike, as they reappear with different identities during three different settings of the novel. The first part of the novel takes place on Planet Orbus, a planet that suffers from ecological problems like global warming, depletion of natural resources, and dust storms. However, the novel opens with news telling that a new planet, Planet Blue, has been discovered. The reader is introduced to Billie Crusoe, an agent from Enhancement Services who explains the possibilities of a new life in Planet Blue during a press conference. She calls the newly discovered planet an "opportunity to do things differently" and admits that humans have "made a few mistakes" on Orbus that have caused the destruction of natural resources (Winterson 4). Billie is also assigned to have two interviews: first, with a woman, Mary McMurphy with a nickname of "Pink", who has asked the Enhancement Services "to be genetically reversed to twelve years old to stop her husband running after schoolgirls" (12) and her second interview is with a robot named Spike who has returned from a space expedition and is scheduled to be disposed of her after the interview since "all information-sensitive robots are dismantled after mission, so that their data cannot be accessed by hostile forces" (Winterson 6). Within this perspective, both Pink's and Spike's bodies are exposed to manipulation by the political system. Pink's desire for the age reversal derives from her constant exposure to the capitalist marketing strategies of cosmetic surgeries that are encouraged by MORE corporation in an attempt to objectify women's body. Likewise, Spike's body is designed by the same capitalist corporation to assure the progress and benefit of the company by subjugating the mental capacity of a nonhuman robot.

The Stone Gods represents how the power structure attempts to reconfigure human bodies by using biotechnology. Particularly, there are a variety of references to the technological interventions on the female body ranging from sexuality to reproduction. Billie is concerned about the prevailing biotechnology practices in terms of reproduction that trouble the position of women in the future where women "don't breed in the womb anymore, and [they] aren't wanted for sex" (Winterson 22). Thus, the transition of women's bodily functions to laboratories destabilizes women's power in a society that is already patriarchal. In other words, women are exposed to double oppressions insofar as their body is defined by patriarchal standards and at the same time becomes a target of the biotechnological experiments that attempt to replicate their body functions. Haraway argues that the Othering practices of biotechnology reduce women's body to objects of consumption (154). Winterson depicts a condition in which in the absence of women's biological value, the dichotomous gender perception is reinforced by the patriarchal system ever more than before. Pink is an ultimate example of the female body's devaluation in the novel. She wants to reverse her age into twelve to attract the attention of her pedophiliac husband, particularly, a celebrity called "Little Senorita" (Winterson 6). Pink explains to Billie her loneliness when her husband spends most of his time in a "pervert's bar" and does not even touch her anymore. As Pink states: "we don't have sex anymore. He says I'm too old" (17). Through the portrayal of the character of Pink, Winterson criticizes the social structure of a patriarchal and capitalist society in which a personality disorder like pedophilia is undermined and instead a remedy of perfect beauty is offered to transform women as an object of male desire. Significantly, Pink can only have her biological age's reversal by the permission of her husband and the Court of Human Rights, which is a patriarchal institution as well. As far as Pink's embodiment is considered from a Deleuzoguattarian perspective, the State apparatus like Enhancement Services may transform biotechnology into a surveillance mechanism at the service of patriarchal systems. In other 
words, the body manipulation of women keeps them busy with passive ideals like physical attractiveness and this allows the authorities to mask their exploitive ideology that deprives women of their basic rights like political and economic agencies. As it is clear in the novel, the Central Power is only run by male politicians and the affluent corporations belong to male owners. Thus, through revisiting the embodiment policies of MORE corporations, Winterson focuses on the ways that the hegemonic political systems exclude women by channeling their desire and accordingly shaping their subjectivity within pre-established norms. Winterson suggests that the only way out to build the space of resistance is to form a posthuman subjectivity. According to Deleuze and Guattari, a posthuman subject makes new assemblages and involves in a becoming process that cannot be manipulated because it comes from the unlimited hybridity of many assemblages.

Billie's second task is to interview Spike, a Robo Sapiens, who is designed by Central Power to function as a flawless calculating brain in space missions. After her return from the expedition, the authorities want to drain her information and then switch her off forever to protect citizens of Central power from the enmity of rival forces. In this perspective, Spike's commodification occurs in a response to the demand of the hegemonic system which seeks to maintain its power by disentangling itself from non-human life. Furthermore, they devalue the agency of nonhuman entities by associating them with the lack of emotions where Billie clarifies, "the great thing about robots, even these Robo sapiens, is that nobody feels sorry for them. They are only machines" and therefore don't require our empathy (Winterson 6). Conversely, Spike shows cyborg emotions and explains that "Robo Sapiens were programmed to evolve [...] within limits, [however] we've broken those limits" (29). Spike evolves into a conscious being, thus, transgressing the boundaries of human and nonhuman, and accordingly resists against the normative power structures that attempt to define and code her within limits. Moreover, despite her physical design that is perfectly beautiful and is meant to fulfill the expectation of the patriarchal gaze, Spike defies the idea of having a static identity by arguing that "gender is a human concept [...] and not interesting" (63). Central Power's attempt to regulate bodies, especially women's bodies, through medical interventions leads to a kind of homogenization that makes everybody "bored to death with sex" (67). However, Spike's perception of love is different from humans in that she defines love as "an experiment" insofar as it is replete with "surprising" possibilities (67). Spike engages in a constant state of becoming, which empowers her to reconfigure a Body without Organs ${ }^{3}$. In contrary to the physical perception of the body as a passive surface, Deleuze and Guattari suggest an alternative view of body that embodies a "plane of consistency," allowing for the flow and interaction of various intensities (89). The main purpose of creating a BwOs is to dismantle the predetermined and constructed norms that are imposed upon a subject. Through forming a BwOs, a subject becomes "more adept at navigating the differentiating forces" transforming the hierarchical patterns that are associated with power relations (Lorraine 5). Deleuzoguattarian conceptualization of a BwOs seeks to define the body in movement. A dynamic body has the potential to open up new possibilities by breaking habits and routines. Accordingly, the body in motion transgresses the limits of the actual body, body in its representational level, and attains the virtual body that embodies new connections. Within this framework, Spike's reconfiguration of a BwOs entails the deterritorialization of constructed norms that define her subjectivity as belonging to a specific category of Robo Sapiens. Furthermore, Spike forms productive assemblages with her surrounding, and this allows her to produce differences and thus, creating haecceitic individuation. This type of individuality is beyond the confinements of subjectivity, it forms a "thisness" that composes of fluid movements and has the capacity to affect and be affected (Deleuze and Guattari 263).

After the interview, Spike mysteriously disappears from Enhancement Services and after a while, Billie and Spike reunite in a spacecraft that is heading to Planet Blue. On their way, they have a conversation that reveals Spike's perception of humanity. She criticizes humans for being selfcentered and claims that the main reason for the environmental degradation on Orbus is the anthropocentric mindset that excludes other species. As she explains "humans always assumed that theirs was the only kind that mattered. That's how you destroyed your planet" (Winterson 65-66). Furthermore, the anthropocentric mindset extends itself to the perception of the body in human and nonhuman beings. At one stage in the novel, Spike expresses her love for Billie and faces her

\footnotetext{
${ }^{3}$ Hereafter BwOs
} 
resistance with an excuse that she is just a robot. In response, Spike asks Billie "what is a human being?" in a world where everybody has undergone genetic modification (63). Here, Winterson refers to the body regulation policies that reconfigure the human body. Furthermore, she highlights the fact that there is not a clear-cut distinction between human and nonhuman bodies but rather they are interconnected and entangled. This entanglement can be better perceived in the love relationship between Spike and Billie as they both experience a posthuman sense of love that is beyond the heteronormative politics of embodiment. Spike and Billie's love is an example of transgressing the hegemonic embodiment norms that categorize the human and nonhuman bodies within a fixed category of existence. To put their love affair in Deleuzoguattarian context, it can be argued that they both extend themselves to the status of a BwOs that allow them to form an alternative perception of the body that is beyond the gender binary.

\section{Abject Bodies Revisited}

The second section of the novel introduces another love story between Billy, a male British sailor, and Spikkers, a male, native, mixed-race islander. Their queer relationship represents a new form of embodiment that is far from the heteronormative gender norms. Regardless of his British origin, Billy falls in love with a racial other. Thus, he creates a space of resistance that allows him to detach from his Britishness and embrace a new individuality that is multiple and hybrid. Similarly, Spikkers transgresses his tribal boundaries and form a new identity that helps him and his lover to live an alternative life on Easter Island. Billy and Spikkers' relationship grows stronger as they exchange information about their cultural background. Meanwhile, Spikkers shares the underlying reasons behind the ecological collapse and the ongoing civil war on the island. Billy and Spikkers live in "intermezzo", an in-between space that welcomes multiplicity and hybridity (Deleuze and Guattari 277). In Deleuzoguattarian terms, the queer relationship of the pair resembles a rhizome in that they are born and reborn endlessly, ceaselessly, transforming from one thing to the next through building new assemblages. Billy and Spikkers merge into each other, thus, there is no longer a single subject or object, but rather a multiplicity of in-betweenness. This form of assemblage proves to be an ultimate example of becoming-revolutionary that allows them to subvert the static conceptualization of human subjectivity. Thus, through locating themselves in a space of resistance, Billy and Spikkers create a more-than-human alliance with a transformative potential to break away the binary logic of heteronormativity.

The third and fourth sections of The Stone Gods take place on Earth in a period known as "Post-3War." Similar to the Billie on Orbus who was a worker in Enhancement Services, the second Billie on Earth is an employee of MORE Futures and her job is to teach Spike, now a bodiless robot, the meaning of being a "human" (Winterson 135). In one of their educational walks, Billie abducts Spike and takes her to "Wreck City", a residue of nuclear war that is described as "a No Zone" where the MORE corporation has yet to take control (151). The inhabitants of Wreck City are mostly alternative people who flee from Tech City to be free of the corporation's surveillance. Thus, Wreck City signifies a place of resistance where the abject people produce a new form of life. In the vicinity of Wreck City, there is a polluted land known as the "Dead Forrest" (170). Friday, a bartender in Wreck City, explains to Billie that the forest is populated by radioactive humans who are left there to die. Winterson links the position of toxic people and their body formation to contemporary capitalism that has made a rapid expansion across the world. Rosi Braidotti argues that capitalism "functions through the incorporation of otherness" and in doing so, it advocates hegemonic structures that have destructive impacts on both planet and humanity (55). MORE entails a hierarchical structure which on the one hand, privileges humans over nonhumans and on the other hand, imposes a social class system that values subordinate citizens of Tech City and excludes rebellious outcasts of Wreck City. In Deleuzoguattarian sense, MORE functions as the State apparatus that subjugate its citizens by using an objectifying logic that reduces their status to either profitable or non-profitable commodities.

\section{Conclusion}

In The Stone Gods, Winterson depicts various kinds of posthuman bodies including Robo Sapiens, queer bodies and radioactive mutants that are explicitly affected by the body politics of capitalism, heteronormative power structures, and humanism. She invites the readers to revise their 
perception of the human and its anthropocentric mindset. Winterson's posthumanist framework in the novel enables establishing an alternative normative standard as a productive space to examine the relationship between humans and other-than humans. Furthermore, Winterson juxtaposes the gender binary with the emergence of the new types of bodies to depict that our contemporary society is entangled with the same dichotomous thinking that excludes and disempower both minority groups and nonhuman. However, Winterson offers signs of hope by introducing a posthuman concept of love that can bring the heterogeneous entities from different identities, nationalities, and species together and produce an alternative form of coexistence.

\section{WORKS CITED}

Braidotti, Rosi. Transpositions: On Nomadic Ethics. Cambridge: Polity Press, 2008.

Braun, Bruce. "Querying Posthumanisms." Geoforum 35.3 (2004): 269-273.

Deleuze, Gilles and Félix Guattari. A Thousand Plateaus: Capitalism and Schizophrenia. Trans. Brian Massumi. London: The Athlone Press, (1980) 1996.

Deleuze, Gilles and Parnet, Claire. Dialogues. Trans. H. Tomlinson and B. Habberjam, London: Athlone Press, 1987.

Haraway, Donna. Simians, Cyborgs, and Women: The Reinvention of Nature. New York: Routledge, 1991.

Lorraine, Tamsin. Deleuze and Guattari's Immanent Ethics Theory, Subjectivity, and Duration. Albany: State University of New York Press, 2011.

Winterson, Jeanette. The Stone Gods. London: Penguin, 2007. 